\title{
Foraging Behaviour of Sri Lanka Yellow-eared Bulbul (Pycnonotus penicillatus) in the Montane Cloud Forests of Horton Plains National Park, Sri Lanka
}

\author{
P. H. S. P. Chandrasiri ${ }^{1}$, W. A. D. Mahaulpatha ${ }^{2} *$ \\ ${ }^{1,2}$ Department of Zoology, Faculty of Applied Sciences, University of Sri Jayewardenepura, Sri Lanka
}

\begin{abstract}
Foraging behaviour of Sri Lanka Yellow-eared Bulbul (Pycnonotus penicillatus) was studied in the tropical montane cloud forests of Horton Plains national park, situated in the highland plateau of the Nuwara Eliya District at the eastern extremity of the central highlands from September 2015 to April 2017. Line transects and opportunistic observations were used to obtain data. Foraging individuals were observed directly or through a binocular from $0600 \mathrm{~h}$ to $1800 \mathrm{~h}$, on three consecutive days per month. Foraging plant types were identified by using field guides. They flew approximately $50.4 \pm 34.2$ (Mean \pm Standard Deviation) meters per minute in search of food with $1.4 \pm 0.7$ stops per minute. Maximum hopping (57\%) was recorded when the birds moved between foraging sites. Maximum number of foraging observations $(95 \%)$ were recorded from cloud forest habitat and least number of foraging observations $(5 \%)$ were recorded from grassland habitats. Observed foraging height was $3.6 \pm 2.9 m$ above ground, and distance to canopy above the bird was $0.8 \pm 0.6 \mathrm{~m}$. Foraging tree height was $4.5 \pm 3.1 \mathrm{~m}$. Majority of the birds (48\%) were feeding within "middle" horizontal position of the trees. P. penicillatus highly utilized (28\%) 'moderate density foliage cover' when foraging. Out of 17 feeding plants observed, Rubus ellipticus was the major feeding plant of P. penicillatus. Exactly $96 \%$ of the birds used to forage on top of the leaves. 'Gulping' was the major food handling technique. Findings of the present study indicated that P. penicillatus utilized plant species of different sizes for foraging and that its preferred foraging habitat is the montane cloud forests.
\end{abstract}

Keywords: Pycnonotus penicillatus, Tropical Montane Cloud Forest, Foraging Behaviour

\section{Introduction}

Sri Lanka Yellow-eared Bulbul (Pycnonotus penicillatus) is a member of the Family Pycnonotidae and the order Passeriformes. This species occurs in forests and nearby gardens, at middle and higher elevations, generally around 900-2000 m, where it is abundant in suitable habitats. It is an endemic and threatened bird, assessed under IUCN global conservation status in the Near Threatened (NT) category, and according to the national conservation status $P$. penicillatus is in Vulnerable (VU) category of the National Red List (MOE, 2012). It is about $20 \mathrm{~cm}$ in length, with a long tail. It has olive coloured upper parts and yellowish under parts. There are yellow ear tufts and a yellow patch below the eye. Sexes are similar in plumage, but young birds are duller than adults. It is a frugivorous bird (Birdlife International 2012). It is distributed throughout the country (Harrison \& Worfolk, 2011; MOE, 2012). Although the general ecology of this species has been studied previously (Henry, 1998), there is a research gap with regard to the specific behavioural studies about foraging. Present paper studied the aspects associated with foraging behaviour including search, attack and foraging sites and food handling techniques of $P$. penicillatus.

\section{Materials and Methods}

The study was conducted at the Horton Plains National Park (HPNP) from September 2015 to April 2017, located at $6^{\circ} 47^{\prime}-6^{\circ} 50^{\prime} \mathrm{N}, 80^{\circ} 46^{\prime}-80^{\circ} 50^{\prime} \mathrm{E}$ (Green, 1990) (Fig. 1). The HPNP occupies an area of 3,160 ha and is contiguous with Peak Wilderness Sanctuary to the west. It is in the Nuwara
Eliya District at the eastern extremity (DWC, 2007). West end of the HPNP plateau is dominated by Kirigalpotta $(2,390$ $\mathrm{m})$ and northern end is dominated by Totupola Kanda $(2,357$ $\mathrm{m})$, respectively second and third highest peaks in the country (Pethiyagoda, 2012). Tropical montane forests and wet pathana grasslands are the two distinct habitats in the park (Gunatilleke \& Gunatilleke, 1990). Tropical montane forest consists about $75 \%$ of the park and wet pathana grassland consists about $25 \%$ of the national park (Gunatilake, 1996).

Three, 100m line transects were established in both of these habitats. Observers walked along these transacts during the morning, mid-day and in the evening on three consecutive days at an approximate speed of ten meters per minute. Opportunistic observations were also used to collect data while casually walking along the well laid down gravel roads in these habitats.

Foraging birds were observed directly and if the bird was feeding at a distance, a binocular $\left(\right.$ Nikon $^{\mathrm{TM}}$ - Monarch, $10 \mathrm{x}$ 50) was used to observe the birds. In every foraging observation, searching behaviour, attack behaviour (attack behaviour is the moment, after the sighting when a capture attempt is made), food handling techniques and foraging site was recorded. When birds were observed searching for food distance covered per unit time was determined by recording the distance between the first observation point to the final observation point where the bird approached a particular food. To find out the actual distance, the observer followed the path of the bird using coordinates of a Global Positioning System (GPS) device (Garmin $^{\mathrm{TM}}$ eTrex 10). Then the distance was divided by the time. The number of

Volume 6 Issue 7, July 2017 


\section{International Journal of Science and Research (IJSR) \\ ISSN (Online): 2319-7064}

Index Copernicus Value (2015): 78.96 | Impact Factor (2015): 6.391

stops was observed separately.

Attack behaviour was subdivided into two main categories as near-perch manoeuvres and aerial manoeuvres. Five categories of near-perch manoeuvres were identified as; gleaning, reaching, hanging, pecking and flaking. Gleaning meant picking food items from a nearby substrate, including the ground, which can be reached without full extension of legs or neck. Reaching meant extending completely the legs or neck upwards, outwards, or downwards. Hanging meant using legs and toes to suspend the body below the feet to reach food that can- not be reached from any other perched position. Pecking meant driving the bill against the substrate to remove some of the exterior of the substrate. Flaking meant brushing aside loose substrate with sideways, sweeping motions of the bill.' Two aerial manoeuvres were identified as leaping and sallying. Leaping meant launching into the air to reach a food item too far for a reach but too close for a sally. Sallying meant flying from a perch to attack a food item'(Remsen \& Robinson, 1990).

The foraging site was categorized as general habitat, vertical position, horizontal position, foliage density and the precise substrate from which the food was taken. General habitats were the major habitats where the foraging behaviour was observed. In vertical position category there were three main sub categories (i) height-above-ground and (ii) distance tocanopy (above bird) (iii) height of the individual plant, which the bird was foraging. Relative position in the foliage column was calculated by the height above ground at which a bird was recorded, divided from the height of the canopy at that point. Horizontal position was subdivided as inner, middle and outer positions of the bird at the tree or bush. Foliage density at the point of foraging observation was recorded using a qualitative scale. This is a scale from "0" to "5" of increasing foliage density within a one meter radius around the bird: " 0 " = no vegetation within the imaginary $1 \mathrm{~m}$ sphere; "1" = very low vegetation density within the sphere (e.g., 95-99\% of all light passes through sphere); "2"= low density, 75-95\% of light passes; "3" = moderate density, 25-75\% of all light passes; "4" = high density, only $5-25 \%$ of light passes; and "5" = extremely dense, $0-5 \%$ of light passes (Remsen \& Robinson, 1990). Foraging substrate of $P$. penicillatuswas subdivided into threecategories as; Plant species, Leaf size, Top or Bottom of leaves. Plants were identified by using field guides (Ashton et al, 1997).

Food handling techniques were categorized according to following criteria: gulp, mash, beat,jab, tear, bite and clasp (Remsen \& Robinson, 1990). Gulp - 'to swallow upon capture without any noticeable manipulation other than being held briefly by the bill.' Mash - 'to squeeze or move around between the mandibles before swallowing; sometimes, juices or pulp are squeezed out of the food and solid portions discarded'(Moermond \& Denslow, 1985). Beat- 'to beat food item against hard substrate .Many small insectivorous birds typically beat insects against branches in a diagonally downward- facing position'(Root, 1967). Jab- 'to peck food item with bill tip , usually while clasped with feet'(Remsen \& Robinson, 1990). Tear - 'to eviscerate or dissect food item into smaller pieces, usually while the food is clasped by one or both feet'
(Remsen \& Robinson, 1990). Bite- 'to bite and remove a section of food item; frugivores that take bites from fruit too large to swallow whole'(Foster,1987). Clasp- 'to hold food item with feet' (Remsen \& Robinson, 1990).

Microsoft Excel ${ }^{\mathrm{TM}}$ was used to store data and to construct graphical illustrations. Minitab $17^{\mathrm{TM}}$ was used for statistical analysis. Pearson correlation was applied to find out relationships between variables.

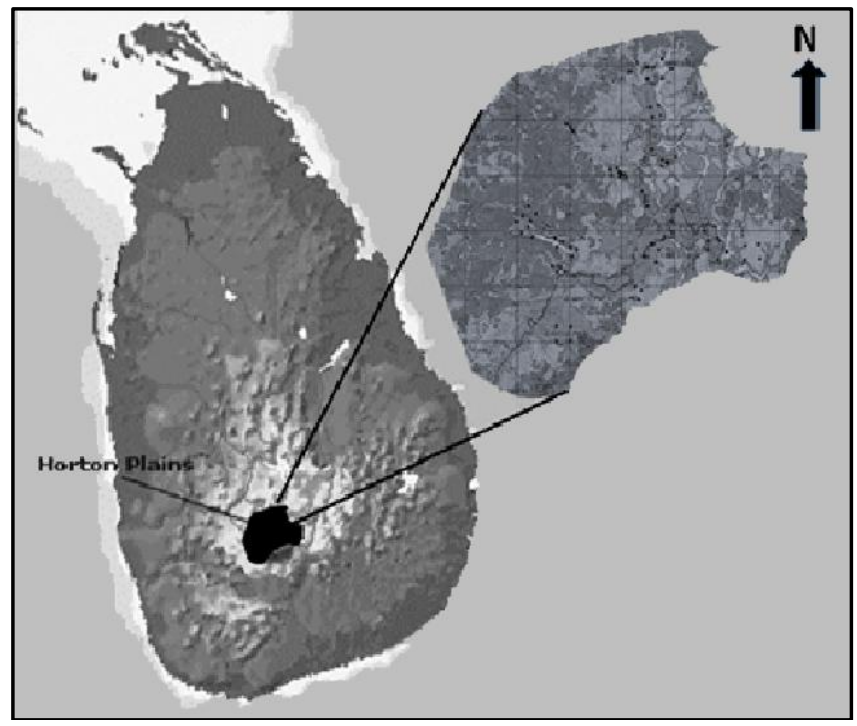

Figure 1: Location of HPNP in Sri Lanka. (Map modified by DWC, 2007)

\section{Results}

Present study revealed that $P$. penicillatus explored $50.4 \pm$ 34.2 (Mean \pm Standard Deviation) meters per minute in search of search food and while foraging made $1.4 \pm 0.7$ stops per minute. Hopping was the most common foraging behaviour $(57.24 \%)$ of $P$. penicillatus when moving between foraging sites. This wasfollowed by fluttering $(22.64 \%)$ and flying behaviour $(12.68 \%)$. Walking was observed only from one bird. Periodically there were climbing and gliding behaviours (Table 1).

Table 1: Behaviours of $P$. penicillatusobserved when moving between foraging sites

\begin{tabular}{|c|c|c|}
\hline Behaviour & Number of Observations & $\%$ \\
\hline Hop & 316 & 57.24 \\
\hline Flutter & 125 & 22.64 \\
\hline Fly & 70 & 12.68 \\
\hline Climb & 28 & 5.07 \\
\hline Glide & 12 & 2.17 \\
\hline Walk & 1 & 0.18 \\
\hline
\end{tabular}

$P$. penicillatus utilized both surface manoeuvres and aerial manoeuvre attack methods (Fig 2). However there were more surface manoeuvres compared to aerial manoeuvres. Gleaning was the major attack method. 'Reaching' 'Leaping' 'Sallying' behaviours were used occasionally. Also they utilized 'Hanging' 'Pecking' and 'Flaking' attack methods.

\section{Volume 6 Issue 7, July 2017 www.ijsr.net}




\section{International Journal of Science and Research (IJSR) \\ ISSN (Online): 2319-7064}

Index Copernicus Value (2015): 78.96 | Impact Factor (2015): 6.391

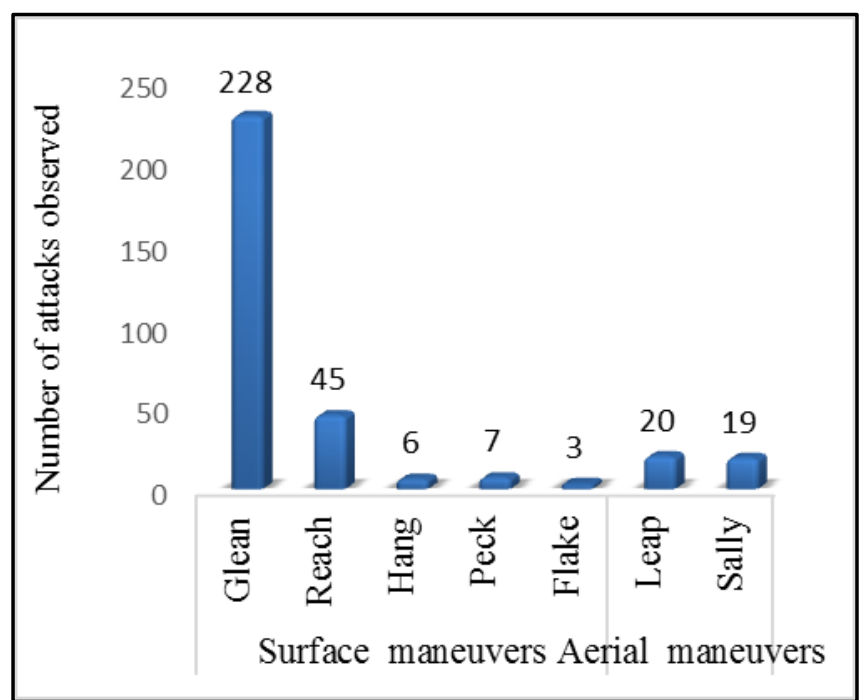

Figure 2: Attack methods of $P$. penicillatus

Maximum number of foraging observations (95\%) was recorded from the forest habitat and only $5 \%$ of foraging observations were recorded from grassland habitat (Fig 3).

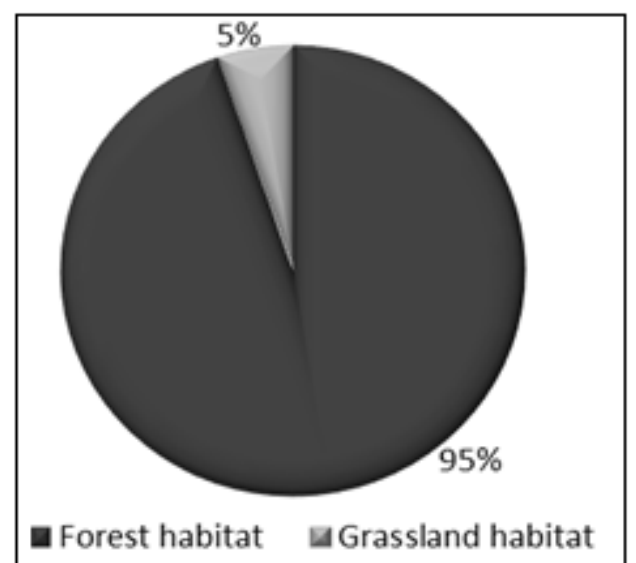

Figure 3: Main habitats of $P$. penicillatus within HPNP

Foraging height of $P$. penicillatus was $3.6 \pm 2.9 \mathrm{~m}(\mathrm{n}=552)$ above ground (Fig 4). Distance to canopy above the bird was $0.8 \pm 0.6 \mathrm{~m}$. Foraging tree height was $4.5 \pm 3.1 \mathrm{~m}$. There was a positive correlation between foraging height of the bird and height of the plant (Pearson correlation $=0.980, \mathrm{P}$-Value $<$ 0.05). Relative foraging position utilized by $P$. penicillatus was $0.7 \pm 0.1 \mathrm{~m}$.

Majority of the birds (48\%) were used to forage at "middle" horizontal position of the plant (Fig 6). "Inner" horizontal position was utilized by least number of birds.

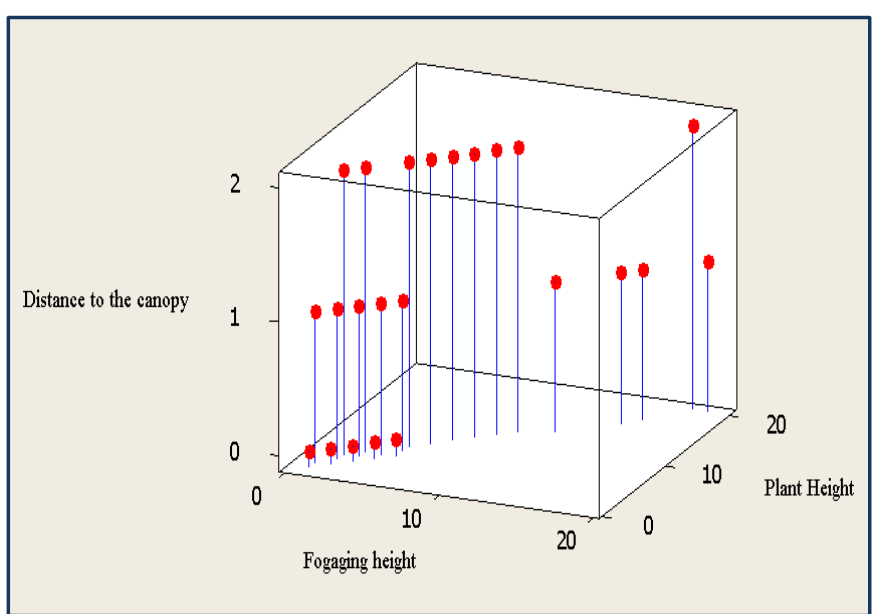

Figure 4: Vertical foraging positions of $P$. penicillatus within HPNP in meters.

P. penicillatus highly utilized (28\%) moderate dense foliage cover for foraging while only $5 \%$ of P.penicillatus utilized extremely dense foliage for foraging (Fig 5).

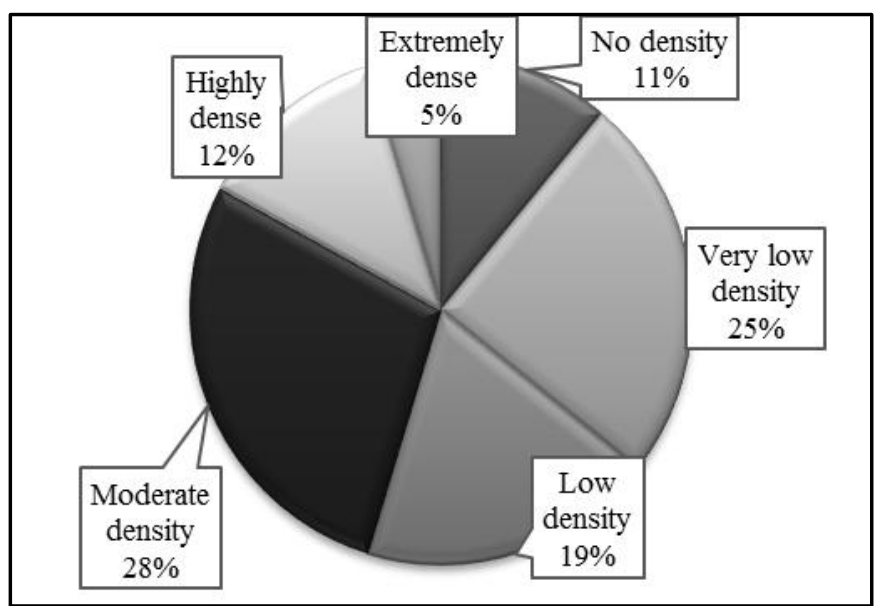

Figure 5: Foliage density of the foraging plants of P.penicillatus

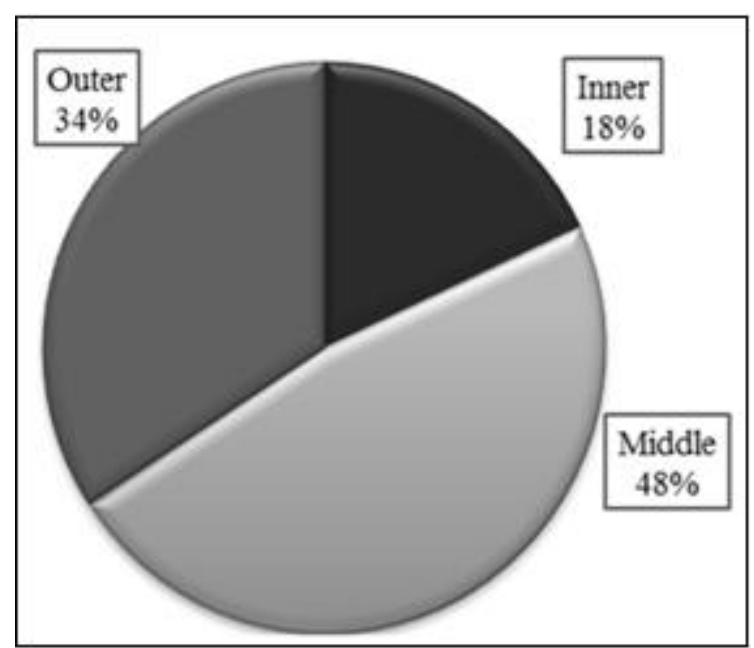

Figure 6: Horizontal foraging position at the foliage

$P$.penicillatus utilized seventeen species of plants for foraging. Rubus ellipticus was the major foraging plant of $P$. penicillatus. Minimum foraging observations were recorded on Strobilanthes sp. They frequently utilized Solanum mauritianum, Symplocos bractealis and Sarcococca 


\section{International Journal of Science and Research (IJSR) \\ ISSN (Online): 2319-7064}

Index Copernicus Value (2015): 78.96 | Impact Factor (2015): 6.391

brevifolia. Trees such as Syzygium sclerophyllum and Eugenia mabaeoides were occasionally preferred (Table 2).

Table 2: Description of Foraging Plant Species of P.penicillatus

\begin{tabular}{|c|c|c|c|}
\hline Plant Species & Order & Family & $\begin{array}{c}\text { Foraging } \\
\text { observations } \\
\%\end{array}$ \\
\hline Rubus ellipticus & Rosales & Rosaceae & 19.65 \\
\hline Solanum mauritianum & Solanales & Solanaceae & 13.68 \\
\hline Symplocos bractealis & Ebenales & Symplocaceae & 11.69 \\
\hline Sarcococca brevifolia & Buxales & Buxaceae & 8.20 \\
\hline Rhodomyrtus tomentosa & Myrtales & Myrtaceae & 7.71 \\
\hline Rubus leucocarpus & Rosales & Rosaceae & 5.97 \\
\hline Passiflora tripartita & Malpighiales & Passifloraceae & 5.22 \\
\hline Berberis ceylanica & Ranunculales & Berberidaceae & 4.98 \\
\hline Cestrum fasciculatum & Solanales & Solanaceae & 4.72 \\
\hline Elaeocarpus coreaceus & Oxalidales & Elaeocarpaceae & 3.73 \\
\hline Solanum lasiocarpum & Solanales & Solanaceae & 3.23 \\
\hline Rhododendron arboreum & Ericales & Ericaceae & 2.73 \\
\hline Rubus indicus & Rosales & Rosaceae & 2.49 \\
\hline Callophyllum walkeri & Theales & Guttiferae & 4.98 \\
\hline Syzygium sclerophyllum & Myrtales & Myrtaceae & 1.74 \\
\hline Eugenia mabaeoides & Myrtales & Myrtaceae & 1.49 \\
\hline Strobilanthes sp & Lamiales & Acanthaceae & 0.50 \\
\hline
\end{tabular}

'Gulp' was the major food handling technique of $P$. penicillatus. They also utilized 'Mash', 'Beat' and 'Bite' techniques occasionally and rarely 'Tear', 'Jab', 'Clasp' techniques (Fig 7).

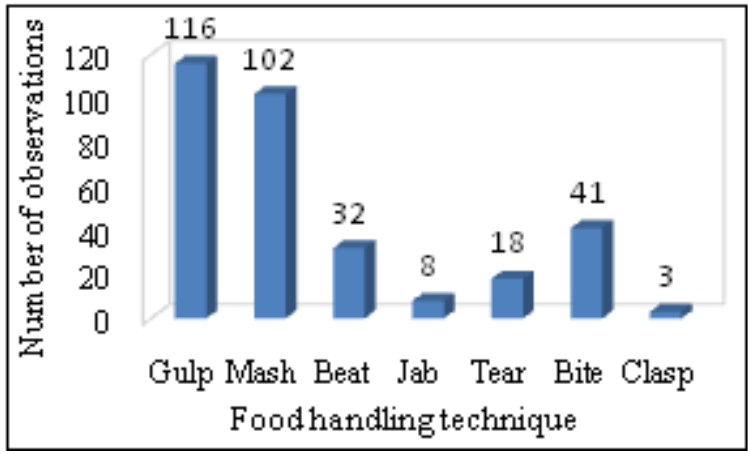

Figure 7: Food handling techniques of $P$. penicillatus

\section{Discussion}

Studying the foraging behaviour and identifying foraging sites of a bird species is important for their conservation. Foraging behaviour includes searching methods, their foraging sites, food and food handling techniques. Foraging sites includes general location and specific substrates. Food taken is important because differences in food taken may provide information on niches, morphology of the bill, and energetics (Remsen \& Robinson, 1990). Food handling method is important, to study cost benefit ratio, of any food type, to study adaptive morphology (Sherry \& McDade 1982) and to study plant frugivore interactions (Howe \& Smallwood,1982).

P. penicillatus is not a shy bird that hides easily (Harrison \& Worfolk, 2011). Therefore the researchers were able to observe and record foraging behaviours of the species easily. It is possible that $P$. penicillatus searched their food sources with several stops to find out actual place of the food. Because some birds vary the duration of foraging pauses as a function of the difficulty of scanning in a given space or locating a particular type of prey (O'brien et al,1990). This species is a forest bird and there is a dense cover of foliage with canopies in there foraging habitat. Therefore, stopping while searching for food is a must to locate the actual prey.

Hopping was the main foraging behaviour when moving between foraging sites. This was because they utilized branches, twigs and foliage of trees, as foraging sites. Holmes and Robinson (1981) suggested that leaf morphology and arrangement (e.g. size, shape, petiole length, distribution along branches, and elevation above twig) strongly affect the foraging behaviour of bird species, which capture prey from nearby substrates. Present study support this observation. In this study gleaning was observed as the major attack method of $P$. penicillatus. Majority of manoeuvres performed by most foliage and ground searching birds are "gleans."(Remsen \& Robinson, 1990).The reason for such behaviour is because 'gleaning' is apparently the most cost effective manoeuvre in terms of energy expenditure (Remsen, 1985).

P.penicillatus utilized mainly the forest habitat for foraging. This could be due to the reason that their food plants were present in higher number at the tropical montane forest compared to the grassland habitat. The species such as Calophyllum walkeri, Syzygium sp. Elaeocarpus coriaceous, Strobilanthes sp. and Sarcococca brevifolia which were utilized heavily by P.penicillatus, were present in higher numbers within the forest. It is well known that $P$. penicillatus is more likely to occur in the forest habitat when compared to the grassland habitat (Chandrasiri \& Mahaulpatha, 2016) where they have enough food.

There was a positive correlation between foraging height, and the plant height with the relative foraging position close to 0.8. Furthermore, Remsen (1985) observed that birds with vertical position values, are close to ' 1 ' are high canopy foragers and those with values close to ' 0 ' as near ground foragers. Therefore, this study revealed that $P$. penicillatus is a canopy forager. They preferred moderate foliage density compared to extreme conditions of minimum and maximum foliage densities. They preferred to sit atop the leaves when they were feeding and rarely used to feed on leaf bottoms.This species highly utilized middle horizontal position of the plants which is important to place the foraging bird in categories with respect to foliage and branch geometry (Remsen \& Robinson, 1990).

$P$. penicillatus exploited a range of vascular plants as foraging plants. They utilized wild fruit species such as, Rubus ellipticus, $R$. indicus and $R$. leucocarpus in high quantities. They also used small tree species such as Symplocos bractealis, Sarcococca brevifolia and Solanummauritianumfor foraging. Gulping was the major food handling technique of $P$. penicillatus. Remsen \& Robinson (1990) observed that the predominant food handling technique of most insectivorous and frugivorous birds is gulping and the finding of this study tally with those observations.

\section{Volume 6 Issue 7, July 2017 www.ijsr.net}




\section{International Journal of Science and Research (IJSR) \\ ISSN (Online): 2319-7064 \\ Index Copernicus Value (2015): 78.96 | Impact Factor (2015): 6.391}

Findings of the present study affirmed that the $P$. penicillatus utilize plant species of different sizes for foraging behaviour. Further studies are recommended to study about food types of this particular species. This bird is mainly foraging in the forest habitat. A slow population decline is likely to be occurring as a result of habitat loss.Habitat decline is continuing in the hills and the status of this species therefore needs monitoring (BirdLife International, 2012). Therefore, it is important to protect the vegetation of the tropical montane cloud forests to ensure the well-being of this important bird species.

\section{Acknowledgement}

Financial assistance by University of Sri Jayewardenepura Research grant No ASP/01/RE/SCI/2015/34. Department of Wildlife Conservation - Permit No WL/3/2/13/15. Mr S.B.R. Lakmal and all the staff members of Horton Plains National Park.Mr.W.D.S.C. Dharmarathne, Mr D.P. Jayakodi, Mr. M.C. Prabhath and Mr. D.P. Jayasekara of Research Crew of Wildlife Circle, Department of Zoology University of Sri Jayewardenepura.Dr. Manoj Liyanage, Mr. P.H.Chandrasiri, Miss P.H.B.N. Chandrasiri and Dr. P.H.C.P. Chandrasiri for co-operation in the field.

\section{References}

[1] Ashton, M.S., Gunatilleke, S., De Zoysa, N., Dassanayake, M.D., Gunatilleke, N. and Wijesundera, S., 1997. A field guide to the common trees and shrubs of Sri Lanka (p. 430). Colombo, Sri Lanka: WHT Publications.

[2] BirdLife International. 2012. Pycnonotus penicillatus. The IUCN Red List of Threatened Species 2012: e.T22712722A38160939.

http://dx.doi.org/10.2305/IUCN.UK.2012 1.RLTS.T22712722A38160939.en

[3] Chandrasiri P.H.S.P. and Mahaulpatha W.A.D., 2016. Distribution of Sri Lanka Yellow-eared Bulbul (Pycnonotus penicillatus) in Tropical Montane Cloud Forests - Horton Plains National Park, Proceedings of the $3^{\text {rd }}$ International Conference on Multidisciplinary Approaches - 2016, Faculty of Graduate, University of Sri Jayewardenepura, Nugegoda, Sri Lanka pp-3

[4] DWC. 2007. Biodiversity Baseline Survey: Horton Plains National Park. Consultancy Services Report prepared by Green, M.J.B. (ed.), De Alwis, S.M.D.A.U., Dayawansa, P.N., How, R., Singhakumara, B.M.P., Weerakoon, D. and Wijesinghe, M.R. Department of Wildlife Conservation, Ministry of Environment and Natural Resources, Colombo. 40 pp.

[5] Foster, M.S., 1987. Feeding methods and efficiencies of selected frugivorous birds. Condor, pp.566-580.

[6] Green, M.J.B., 1990. IUCN directory of South Asian protected areas. IUCN.

[7] Gunatilleke C. V. S. and Gunatilleke, I. A. U. N., 1990. Distribution of Floristic Richness and Its Conservation in Sri Lanka., Conservation Biology, Vol. 4, No. 1 (Mar., 1990), pp. 21-31

[8] Gunatilake, C.V.S., 1996. A nature guide to the world's end trail Horton Plains.

[9] Harrison, J. and Worfolk, T., 2011. A field guide to the birds of Sri Lanka. Oxford University Press.
[10] Henry, G.M., 1998. A guide to the birds of Sri Lanka. Oxford University Press, USA.

[11] Holmes, R.T. and Robinson, S.K., 1981. Tree species preferences of foraging insectivorous birds in a northern hardwoods forest. Oecologia, 48(1), pp.31-35.

[12] Howe, H.F. and Smallwood, J., 1982. Ecology of seed dispersal. Annual review of ecology and systematics, 13(1), pp.201-228.

[13] Moermond, T.C. and Denslow, J.S., 1985. Neotropical avian frugivores: patterns of behaviour, morphology, and nutrition, with consequences for fruit selection. Ornithological Monographs, pp.865-897.

[14] MOE. 2012. The National Red List 2012 of Sri Lanka; Conservation Status of the Fauna and Flora. Ministry of Environment, Colombo, Sri Lanka. viii $+476 \mathrm{pp}$

[15] O’brien, W.J., Browman, H.I. and Evans, B.I., 1990. Search strategies of foraging animals. American Scientist, 78(2), pp.152-160.

[16] Pethiyagoda, R. 2012. Horton Plains Sri Lanka's Cloudforest National Park, Wildlife Heritage Trust, Lake Crescent, Colombo 2, Sri Lanka

[17]Remsen Jr, J.V., 1985. Community organization and ecology of birds of high elevation humid forest of the Bolivian Andes. Ornithological Monographs, pp.733756.

[18]Remsen Jr, J.V. and Robinson, S.K., 1990. A classification scheme for foraging behaviour of birds in terrestrial habitats. Studies in avian biology, 13, pp.144160.

[19] Root, R.B., 1967. The niche exploitation pattern of the blue-gray gnatcatcher. Ecological monographs, 37(4), pp.317-350.

[20] Sherry, T.W. and McDade, L.A., 1982. Prey selection and handling in two neotropical hover-gleaning birds. Ecology, pp.1016-1028.

\section{Author Profile}

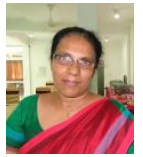

W.A.D Mahaulpatha is Professor, Department of Zoology, Faculty of Applied Sciences, University of Sri Jayewardenepura, Sri Lanka



P.H.S.P. Chandrasiri is Ph.D. Student, Department of Zoology, Faculty of Applied Sciences, University of Sri Jayewardenepura, Sri Lanka

\section{Volume 6 Issue 7, July 2017 www.ijsr.net}

